\author{
MARIUSZ JABŁOŃSKI \\ ORCID: 0000-0001-8347-1884 \\ Uniwersytet Wrocławski \\ Katedra Prawa Konstytucyjnego
}

\title{
DANE SĘDZIÓW POPIERAJĄCYCH ZGŁOSZENIA KANDYDATÓW NA CZŁONKÓW KRAJOWEJ RADY SĄDOWNICTWA JAKO INFORMACJA PUBLICZNA
}

\begin{abstract}
Abstrakt: W opracowaniu poruszone zostały kwestie dotyczące uznania treści załączników do zgłoszeń kandydatów na członków Krajowej Rady Sądownictwa za informację publiczną, udostępnianą na podstawie przepisów ustawy o dostępie do informacji publicznej, w zakresie danych sędziów udzielających takiego poparcia.

Słowa kluczowe: informacja publiczna, jawność, ograniczenie dostępu do informacji publicznej, Krajowa Rada Sądownictwa, załączniki do zgłoszeń kandydatów na członków Krajowej Rady Sądownictwa, prywatność
\end{abstract}

\section{SŁOWO WSTĘPNE}

Kiedy Zgromadzenie Narodowe 2 kwietnia 1997 roku uchwało Konstytucję $\mathrm{RP}^{1}$, trudno się było spodziewać, że ponad dwadzieścia lat po tej dacie jednym $\mathrm{z}$ bardziej interesujących zagadnień dotyczących funkcjonowania państwa będzie kwestia realizacji prawa do informacji o działalności władzy publicznej oraz osób pełniących funkcje publiczne. Okazało się jednak, że praktyka sprawowania władzy przez różne organy, a w szerszym zakresie — specyfika różnego rodzaju procesów decyzyjnych kierowanych przez osoby pełniące funkcje publiczne, przyczyni się do intensyfikacji zainteresowania pozyskaniem informacji ich dotyczących, co wiąże się w sposób oczywisty z realizacją prawa na postawie treści art. 61 Konstytucji RP oraz postanowień ustawy o dostępie do informacji publicznej (dalej: udip)².

${ }^{1}$ Konstytucja RP z dnia 2 kwietnia 1997 roku (Dz.U. Nr 78, poz. 483 ze zm.).

${ }^{2}$ Ustawa z dnia 6 września 2001 roku (tekst jedn. Dz.U. z 2019 r. poz. 1429). Do najnowszych opracowań trzeba zaliczyć: Dostęp do informacji publicznej na wniosek w praktyce jednostek samorzadu terytorialnego, red. J. Wyporska-Frankiewicz, Warszawa 2019; K. Tomaszewska, Dostęp do informacji publicznej w świetle obowiazujacych i przyszłych regulacji, Warszawa 2019; Dostęp do informacji publicznej, red. P. Szustakiewicz, Warszawa 2019. 
Sprawą, która wywołała ostatnio wiele dyskusji, była kwestia udostępnienia jako informacji publicznej załączników do zgłoszeń kandydatów na członków Krajowej Rady Sądownictwa w zakresie wykazów sędziów popierających indywidualne kandydatury ubiegających się o jego uzyskanie. Zobowiązany (w imieniu Sejmu — Szef Kancelarii Sejmu) ${ }^{3}$ stwierdzil, że przepisy ustawy z dnia 12 maja 2011 roku o Krajowej Radzie Sądownictwa ${ }^{4}$ (art. 11c) kształtują odrębne zasady i tryb rozpatrywania konkretnych żądań i w związku z tym na podstawie art. 1 ust. 2 udip to właśnie one mają zastosowanie w tej sprawie. Uznając, że przepisy te wyłączają dopuszczalność (i możliwość) ujawnienia takiej informacji, a ponadto iż udzielenie poparcia przez sędziego kandydatowi na stanowisko członka KRS nie jest informacją o warunkach powierzenia funkcji, odmówił udostępnienia takiej informacji ${ }^{5}$.

Rozstrzygnięcie to zostało następnie zaskarżone do sądu. Sądy administracyjne (najpierw $\mathrm{WSA}^{6}$, a potem $\mathrm{NSA}^{7}$ ) bez cienia jakichkolwiek wątpliwości uznały, że taka informacja jest informacją publiczną i musi zostać udostępniona na podstawie udip w zakresie, który pozwala na zidentyfikowanie danych osoby pełniącej funkcję publiczną (to znaczy sędziego udzielającego poparcia). Mimo że wstępnie przedstawiciele Kancelarii Sejmu obiecywali udostępnić przedmiotową informację ${ }^{8}$, ostatecznie, w następstwie wydanych przez Prezesa Urzędu Ochrony Danych Osobowych (dalej: PUODO) postanowień (dwa postanowienia z dnia 29 sierpnia 2019 roku) $)^{9}$ z obietnicy tej w 2019 roku się nie wywiązali. W uzasadnieniu takiego działania powołano się na fakt zobowiązania Kancelarii Sejmu przez PUODO do ograniczenia przetwarzania danych osobowych zawartych w wykazie sędziów popierających zgłoszenia kandydatów do Krajowej Rady Sądownictwa poprzez nakazanie powstrzymania się od ich upubliczniania oraz udostępniania w jakiejkolwiek formie innym podmiotom do czasu wydania decyzji kończącej postępowanie w niniejszej sprawie ${ }^{10}$. Do 14 lutego 2020 roku listy te pozostały nieujawnione. Jednak po zaskarżeniu postanowień PUODO przez Rzecznika Praw Obywatelskich WSA w Warszawie uchylił je ${ }^{11}$ i choć jego rozstrzygnięcie nie

${ }^{3}$ Sejm Rzeczypospolitej Polskiej jako organ władzy publicznej, reprezentowany przez Szefa Kancelarii Sejmu na zasadzie z art. 202c Regulaminu Sejmu, jest podmiotem obowiązanym do udostępnienia informacji publicznej na podstawie art. 4 ust. 1 pkt 1 udip.

${ }_{4}^{4}$ Tekst jedn. Dz.U. z 2018 r. poz. 389.

${ }^{5}$ Pomijam w opracowaniu kwestię zasadności odmowy udostępnienia list poparcia udzielanego przez grupę 2000 obywateli, co również było przedmiotem żądania wnioskodawcy.

${ }^{6}$ Wyrok WSA w Warszawie z dnia 29 sierpnia 2018 roku, sygn. II SA/Wa 484/18.

7 Wyrok NSA z dnia 28 czerwca 2019 roku, sygn. I OSK 4282/18.

8 Warto podkreślić, że wyrok NSA wraz z uzasadnieniem wpłynął do Kancelarii Sejmu 16 lipca 2019 roku.

${ }^{9}$ Zob. ZSPU.440.555.2019.AZ.I/47241.

${ }^{10} \mathrm{~W}$ uzasadnieniu postanowienia PUODO wskazuje się, że „W treści ww. skargi Skarżący podniósł, iż Kancelaria przystąpiła do upublicznienia jego danych osobowych w zakresie imienia, nazwiska, nr PESEL oraz miejsca zatrudnienia, zawartych na liście poparcia kandydata do Krajowej Rady Sądownictwa — sędziego".

11 Wyrok WSA w Warszawie z dnia 24 stycznia 2020 roku, sygn. II SA/Wa 1927/19. 
było prawomocne, okazało się, że Kancelaria Sejmu ujawniła żądane informacje w zakresie obejmującym dane identyfikujące sędziego (imię i nazwisko) oraz sąd, w którym pełni on swoją funkcję, pomimo że PUODO nie zakończył swojego postępowania i oczywiście nie uchylił wydanych wcześniej postanowień.

Mając to na uwadze, warto wskazać argumenty uzasadniające uznanie przedmiotowych wykazów za informację publiczną, a także dokonać oceny legalności (praworządności) działań podejmowanych nie tylko przez zobowiązanego (Szefa Kancelarii Sejmu), ale też inne organy państwowe.

\section{DZIAŁALNOŚĆ SĄDÓW JAKO ŹRÓDŁO INFORMACJI PUBLICZNEJ}

W chwili obecnej, a więc prawie dwadzieścia lat od momentu wejścia w życie postanowień udip i uwzględnienia kształtującej się w tym okresie sądowej identyfikacji sprawy publicznej (w rozumieniu treści art. 1 ust. 1), nie budzi wątpliwości ${ }^{12}$, że:

1. sądy jako organy jednej z trzech konstytucyjnych władz nie tylko dysponują olbrzymim zasobem informacyjnym, ale (ze względu na realizację konstytucyjnych i ustawowych kompetencji) w istotnym zakresie kreują informację publiczną i są w oczywisty sposób zobowiązane do merytorycznego rozpatrywania żądań opartych na treści art. 61 Konstytucji RP i postanowień udip;

2. sędziowie ze względu na ich status ustrojowy i systemowy pełnią funkcję publiczną ${ }^{13}$, a w konsekwencji informacje ich dotyczące bądź wiążące się z powierzeniem i wykonywaniem przez nich funkcji stanowią informację publiczną;

3. informacją publiczną $\mathrm{w}$ rozumieniu udip są dane znajdujące się $\mathrm{w}$ posiadaniu sądu, a dotyczące między innymi: dysponowania majątkiem publicznym ${ }^{14}$, wydatkowania środków publicznych ${ }^{15}$, osoby sędziego i innych pracowników zatrudnionych w sądzie (na przykład wieku sędziego, spełnienia wymogów przez

$12 \mathrm{~W}$ literaturze wskazuje się, że „W posiadaniu sądów są dwie zasadnicze grupy informacji publicznych, pierwsza dotyczy realizowanej przez sądy funkcji orzeczniczej oraz druga organizacji sądów" - A. Piskorz-Ryń, Obowiązki informacyjne sądu w świetle ustawy o dostępie do informacji publicznej, „Orzecznictwo Sądu Apelacyjnego w Łodzi” 2015, nr 2. Sędzia - osoba publiczna czy prywatna? Granice dostęp do informacji publicznej i ochrona danych osobowych, s. 11. http:// www.lodz.sa.gov.pl/upload/f/15/11/5/992 osaw_nr 215.pdf (dostęp: 15.05.2019). Warto podkreślić, że „zasadniczo” nie oznacza „wyłącznie”. Odrębną kategorią informacji publicznej są na przykład informacje dotyczące samego sędziego.

13 Trybunał Konstytucyjny w wyroku z dnia 15 stycznia 2009 roku, sygn. K 45/07, podkreślił, że zgodnie z fundamentalną zasadą ustroju sądów sędzia wykonuje władzę sądowniczą w sądzie, w którym ma swoje miejsce służbowe.

${ }^{14} \mathrm{~Np}$. wyrok NSA z dnia 10 stycznia 2014 roku, sygn. I OSK 2075/13.

$15 \mathrm{~W}$ zakresie wynagrodzeń również pracowników sądu i prokuratury zob. wyrok WSA w Warszawie z dnia 4 lutego 2014 roku, sygn. II SAB/Wa 648/13; oraz wyrok NSA z dnia 29 września 2013 roku, sygn. I OSK 822/13.

Przegląd Prawa i Administracji CXX, 2020, cz. 1 i 2

(C) for this edition by CNS 
kandydata na referendarza, okresu pracy pracownika administracyjnego) ${ }^{16}$, sprawozdań z wizytacji zakładów karnych oraz aresztów śledczych ${ }^{17}$, rozstrzygnięć (prawomocnych i nieprawomocnych) sądowych ${ }^{18}$ (wyroków ${ }^{19}$ i postanowień) ${ }^{20}$,

16 Por. wyroki WSA: w Gdańsku z dnia 8 maja 2013 roku, sygn. II SA/Gd 164/13; w Warszawie z dnia 27 kwietnia 2012 roku, sygn. II SAB/Wa 51/12; z dnia 13 września 2012 roku, sygn. II SA/Wa 1002/12; z dnia 5 grudnia 2012 roku, sygn. II SA/Wa 1716/12; w Gorzowie Wielkopolskim z dnia 17 września 2014 roku, sygn. II SAB/Go 72/14; w Warszawie z dnia 4 grudnia 2014 roku, sygn. II SAB/ Wa 606/14 oraz II SAB/Wa 589/14 (też z 4 grudnia 2014 roku); czy wyrok NSA z dnia 5 marca 2013 roku, sygn. I OSK 2872/12. „Osoba pełniąca funkcje publiczne, zdaniem sądu, musi liczyć się z zainteresowaniem opinii publicznej" - wyrok WSA w Szczecinie z dnia 6 listopada 2013 roku, sygn. II SA/ Sz 935/13. Odmiennie wyrok WSA w Opolu z dnia 2 grudnia 2014 roku, sygn. II SAB/Op 67/14. Na temat różnych form anonimizacji danych personalnych sędziów por. wyrok WSA w Białymstoku z 4 listopada 2014 roku, sygn. II SAB/Bk 69/14 — w zakresie zastąpienia imienia i nazwiska sędziego cyfrą; WSA w Poznaniu z 13 listopada 2014 roku, sygn. II SAB/Po 71/14. Szerzej na temat relacji na płaszczyźnie dostęp do informacji publicznej, ochrona prywatności i danych osobowych zob. M. Sakowska-Baryła, Wspótstosowanie ustaw o dostępie do informacji publicznej i ochronie danych osobowych przy udostępnianiu informacji o osobie petniacej funkcje publiczna, „Orzecznictwo Sądu Apelacyjnego w Łodzi” 2015, nr 2. Sędzia - osoba publiczna czy prywatna? Granice dostepu do informacji publicznej i ochrona danych osobowych, s. 31 n., http://www.lodz.sa.gov.pl/upload/f/15/11/5/992_osaw_ nr_215.pdf(dostęp: 15.05.2019); M. Wilbrandt-Gotowicz, Prywatność osoby fizycznej jako ograniczenie jawności informacji publicznych (w świetle orzecznictwa sądów administracyjnych), [w:] Jawność i jej ograniczenia, t. 4. Znaczenie orzecznictwa, red. M. Jaśkowska, Warszawa 2014, s. 172 n.

17 Jak wskazały sądy, takie sprawozdanie zawiera informację publiczną; por. wyrok WSA w Gdańsku z dnia 5 listopada 2014 roku, sygn. II SA/Gd 112/14; w Gorzowie z dnia 3 grudnia 2014 roku, sygn. II SAB/Go 106/14; w Gliwicach z dnia 14 października 2014 roku, sygn. WSA IV SAB/ G1 106/14.

${ }^{18} \mathrm{~W}$ tym zakresie można też wskazać bardzo szerokie definiowanie takiego dostępu, na przykład: „Informacją publiczną są dane wynikające z urządzeń ewidencyjnych prowadzonych przez organ. Przepis art. 6 ust. 1 pkt 3 lit. »e« i »f« u.d.i.p. wprost wskazuje, iż udostępnieniu podlega informacja publiczna, w szczególności o zasadach funkcjonowania podmiotów, o których mowa $\mathrm{w}$ art. 4 ust. 1, w tym o stanie przyjmowanych spraw, kolejności ich załatwiania lub rozstrzygania oraz o prowadzonych rejestrach, ewidencjach i archiwach oraz o sposobach i zasadach udostępniania danych w nich zawartych. Wobec tego przyjąć należy, iż informację publiczną podlegającą udostępnieniu w trybie ustawy, jako że wynikającą z urządzeń ewidencyjnych prowadzonych przez organ, stanowią daty wniesienia pozwu, sygnatury akt, informacja, czy orzeczenia wydane w sprawach są prawomocne, czy były kwestionowane w drodze środków zaskarżenia oraz podania wykazu spraw wniesionych przez określony podmiot, które są obecnie w toku" - wyrok WSA w Lodzi z dnia 9 października 2014 roku, sygn. II SAB/Łd 110/14.

${ }^{19} \mathrm{~W}$ odniesieniu do wyroków sądów w sprawie karnej bez względu na formę jego upublicznienia (ogłoszenia czy też wyłożenia w sekretariacie Wydziału Karnego według art. 418a k.p.k.) sąd uznał, że stanowią one informację publiczną, a w związku z tym odmowa jego udostępnienia winna nastąpić w formie decyzji administracyjnej — zob. wyrok NSA z dnia 11 sierpnia 2011 roku, sygn. I OSK 933/11. Podstawą takiej decyzji nie może być jednak ochrona tajemnicy zawodowej. Warto natomiast zauważyć, że „Informacją publiczną jest każde orzeczenie sądu bez względu na przymiot prawomocności, bowiem od chwili wydania funkcjonuje w obrocie prawnym niezależnie od tego, czy zostanie ewentualnie wzruszone" - A. Piskorz-Ryń, op. cit., s. 13 z odwołaniem do wyroku NSA z dnia 21 sierpnia 2013 roku, sygn. I OSK 754/13, http:/www.lodz.sa.gov.pl/ upload/f/15/11/5/992_osaw_nr_215.pdf (dostęp: 15.02.2020).

${ }^{20}$ Jak podkreśla się już od dawna, „orzeczenia sądowe — zarówno wyroki, jak i postanowienia - jako wydane w sprawie przez sąd w ramach jego działalności orzeczniczej opartej na 
prawomocnych postanowień wraz z uzasadnieniem umorzenia postępowania ${ }^{21}$, opinii biegłego oraz postanowienia o umorzeniu postępowania przygotowawczego $^{22}$, konkretnego dokumentu znajdującego się w aktach sprawy ${ }^{23}$; a także tych, które dotyczą bezpośrednio innych czynności sędziego, takich jak na przykład:

— oświadczeń sędziego składanego do akt sprawy dotyczącego jego wyłączenia $^{24}$,

- kwalifikacji zawodowych, udziału w postępowaniach dyscyplinarnych, wynagrodzeń, orzekanych kar dyscyplinarnych, zgody na podjęcie dodatkowego zatrudnienia ${ }^{25}$.

Mając to na uwadze, możemy uznać, że treść art. 1 ust. 1 udip obejmuje modelowo każdą informację, która dotyczy aktualnej wiedzy o sprawach publicznych, czyli w sumie wszystkich działań (ewentualnie zaniechań) charakterystycznych i odrębnie konkretyzowanych wobec specyfiki podmiotu (organu) zobowiązanego, związanych z wykonywaniem prawem przewidzianych zadań, obowiązków i kompetencji, zarówno w odniesieniu do poszczególnych osób piastujących funkcję publiczną, jak i przejawów, form, a także skutków działalności (zaniechań) poszczególnych jego struktur organizacyjnych (osób pełniących funkcje publiczne) $)^{26}$.

Za źródło informacji publicznej przyjmuje się natomiast, zgodnie z istotą rozwiązań ujętych w treści art. 3 ust. 1 udip ${ }^{27}$ :

— dokument urzędowy;

przepisach powszechnie obowiązującego prawa, są danymi publicznymi i podlegają udostępnieniu po ich zanonimizowaniu" - wyrok NSA z dnia 11 sierpnia 2011 roku, sygn. I OSK 933/11; zob. też wyroki WSA: w Gorzowie Wielkopolskim z dnia 3 kwietnia 2014 roku, sygn. II SA/Go 127/14; w Warszawie z dnia 18 marca 2014 roku, sygn. II SAB/Wa 718/13 i z dnia 5 września 2013 roku, sygn. II SAB/Wa 285/13; czy w Gdańsku z dnia 5 czerwca 2013 roku, sygn. II SA/Gd 185/13.

${ }^{21}$ Por. wyrok WSA w Krakowie z dnia 20 listopada 2009 roku, sygn. II SAB/Kr 82/09.

${ }^{22}$ Np. wyrok WSA w Gdańsku z dnia 16 grudnia 2015 roku, sygn. SAB/Gd 176/15.

${ }^{23}$ Zob. np. wyrok WSA w Łodzi z dnia 5 listopada 2014 roku, sygn. II SA/Ld 621/14, w którym za zasadne uznano wydanie decyzji o odmowie.

24 „Sędzia jest bowiem funkcjonariuszem publicznym w rozumieniu przepisów ustawy z dnia 6 czerwca 1967 r. Kodeks karny (Dz.U. nr 88, poz. 553, ze zm.) — art. $115 \S 13$ pkt 3, a oświadczenie o wyłączeniu składane jest do akt sprawy w ramach jego kompetencji i obowiązków, a zatem pozostaje w związku z wykonywaną funkcją publiczną, ale ze względu na zakres wniosku chodzi tu o informację przetworzoną" - wyrok WSA w Gdańsku z dnia 4 grudnia 2013 roku, sygn. II SAB/ Gd 212/13; por. wyrok WSA w Gdańsku z dnia 12 marca 2014 roku, sygn. II SAB/Gd 215/13.

${ }^{25}$ M. Sakowska-Baryła, op. cit., s. 48-49 i omówione tam orzecznictwo.

${ }^{26}$ Zauważmy, że w dużym zakresie łączy się tu element podmiotowy z przedmiotowym: „Informacją publiczną będzie każda wiadomość wytworzona lub odnosząca się do władz publicznych, a także odnosząca się do innych podmiotów wykonujących funkcje publiczne w zakresie wykonywania przez nie zadań w zakresie władzy publicznej” - wyrok NSA z dnia 12 grudnia 2006 roku, sygn. I OSK 123/06; por. wyroki WSA w Warszawie z dnia 28 stycznia 2009 roku, sygn. II S.A./Wa 1542/08; oraz z dnia 3 sierpnia 2011 roku, sygn. II SAB/Wa 187/11.

27 Szerzej zob. M. Jabłoński, Udostępnienie informacji publicznej w formie wglądu do dokumentu, Wrocław 2013, s. $145 \mathrm{n}$.

Przegląd Prawa i Administracji CXX, 2020, cz. 1 i 2

(C) for this edition by CNS 
— inne dokumenty (tak zwane materiały urzędowe) tworzące dokumentację określonej sprawy będącej przedmiotem rozstrzygania przez sąd $\mathrm{d}^{28}$;

— sumę wszystkich informacji związanych z dokumentacją znajdującą się w posiadaniu zobowiązanego, czyli: wystąpienia, oceny dokonywane ,przez organy władzy publicznej, niezależnie, do jakiego podmiotu są one kierowane i jakiej sprawy dotyczą", a nawet fakty i zdarzenia towarzyszące działalności zobowiązanego czy czynności podejmowanych przez konkretne osoby pełniące funkcję publiczną ${ }^{29}$.

\section{PEŁNIENIE FUNKCJI PUBLICZNEJ PRZEZ SĘDZIEGO}

Nie budzi też wątpliwości, że pojęcie „osoby pełniącej funkcję publiczną” należy wiązać z osobą wykonującą swoje obowiązki w ramach szeroko rozumianej służby publicznej. W literaturze podkreśla się, że chodzi tu o osoby, które pracują „we wszystkich wyróżnionych konstytucyjnie władzach"30. W takim ujęciu chodzi o te wszystkie osoby, które opierając się na istniejących zasadach i formach nawiązania stosunku pracy (wybór, powołanie, mianowanie, umowa o pracę), stają się osobami (nie zawsze muszą nawet uzyskiwać status pracowniczy) umocowanymi do realizacji zadań poszczególnych władz, a w szerszym zakresie — zadań publicznych. Będzie to więc oczywiście również sędzia każdego z sądów, który osobiście realizuje zadania publiczne w ramach zdefiniowanej prawem struktury organów władzy sądowniczej. Jak podkreślał Trybunał Konstytucyjny,

Podejmując próbę wskazania ogólnych cech, jakie będą przesądzały o tym, że określony podmiot sprawuje funkcję publiczną, można bez większego ryzyka błędu uznać, iż chodzi o takie stanowiska i funkcje, których sprawowanie jest równoznaczne z podejmowaniem działań wpływających bezpośrednio na sytuację prawną innych osób lub łączy się co najmniej z przygotowywaniem decyzji dotyczących innych podmiotów. Spod zakresu funkcji publicznej wykluczone są zatem takie stanowiska, choćby pełnione w ramach organów władzy publicznej, które mają charakter usługowy lub techniczny ${ }^{31}$.

Sędzia w żadnym razie nie wykonuje czynności usługowych ani w żadnym razie nie można jego stanowiska identyfikować ze stanowiskiem technicznym. W najpełniejszym tego słowa znaczeniu sąd rozstrzyga spory prawne, a w konsekwencji definiuje sytuację prawną osób (podmiotów, stron postępowania sądowego), działając w tym zakresie na podstawie i w graniach prawa.

${ }^{28}$ Np. wyrok WSA w Warszawie z dnia 3 stycznia 2011 roku, sygn. II SAB/Wa 264/10; wyrok NSA z dnia 18 września 2008 roku, sygn. I OSK 315/08.

${ }^{29} \mathrm{~Np}$. wyrok NSA z dnia 27 stycznia 2012 roku, sygn. I OSK 2130/11.

30 J. Boć, Komentarz do art. 60 Konstytucji RP, akapit II, [w:] Konstytucje Rzeczypospolitej oraz komentarz do Konstytucji RP z 1997 roku, red. J. Boć, Wrocław 1998, s. 112.

31 Wyrok TK z dnia 20 marca 2006 roku, sygn. K 17/05. 
Jednocześnie trzeba zwrócić uwagę, że jakakolwiek koncepcja zakładająca, że informacje dotyczące ustawowo zdefiniowanych kompetencji czy też uprawnień (obowiązków) zdefiniowanych przez ustawodawcę, a dotyczących sędziego, nie wiążą się z pełnieniem przez niego przedmiotowej funkcji, jest nie tylko nielogiczna, lecz przede wszystkim nie znajduje jakiegokolwiek umocowania w systemowym rozumieniu istoty informacji publicznej dotyczącej działalności osoby pełniącej funkcję publiczną. Informacja taka odnosi się bowiem do realizacji upoważnienia (legitymacji) sędziego do podjęcia określonego typu czynności (w tym udzielenia poparcia innemu sędziemu kandydującemu na funkcję członka KRS) nakierowanych na osiągnięcie zamierzonego rezultatu. Jest to równocześnie oświadczenie woli sędziego udzielającego poparcia, które kierowane jest do innego organu państwowego. Jedynie prawidłowe poparcie może być podstawą przyjęcia zgłoszenia i podjęcia kolejnych działań dotyczących procedury powołania członka KRS. Nie tylko ten dokument, lecz także wszystkie inne związane z przeprowadzeniem takiej procedury dotyczą więc sprawy publicznej w rozumieniu art. 1 ust. 1 udip. Warto tu zauważyć, że zgodnie z treścią art. 5 ust. 2 udip pełnienie funkcji publicznej znacząco ogranicza zasadność powoływania się na ochronę prywatności jako przesłankę ograniczenia dostępu do informacji publicznej. W wypadku sędziów chodzi tu nie tylko o informacje dotyczące powierzenia, ale też wykonywania funkcji. W każdym przypadku, gdy informacje takie mają związek z pełnieniem tych funkcji, będą musiały one zostać udostępnione, a ochrona prywatności nie będzie mogła stać temu na przeszkodzie. W sytuacji, w której w związku z wykonywaniem swojej funkcji (i tylko wtedy, gdy się ją rzeczywiście wykonuje) legalne i dopuszczalne staje się udzielenie poparcia kandydatowi na członka KRS, twierdzenie, że taka informacja wykracza poza rozumienie sprawy publicznej, stanowi nadużycie prawa.

\section{ISTOTA ROZSTRZYGNIĘĆ SĄDÓW ADMINISTRACYJNYCH W SPRAWIE UDOSTĘPNIENIA LIST POPARCIA}

Analizując treść uzasadnień orzeczeń sądów administracyjnych, konieczne jest zwrócenie uwagi na kilka istotnych elementów:

— po pierwsze, w sposób jednoznaczny potwierdzono w nich, że żądanie dotyczyło informacji publicznej;

— po drugie, logicznie i systemowo racjonalnie uzasadniono, że przepisy ustawy o KRS nie kształtują odrębnych od udip zasad udostępniania informacji publicznej, co w konsekwencji oznacza konieczność stosowania tych drugich ${ }^{32}$;

32 „Regulacja zawarta w przepisie art. 11c ustawy o KRS ma charakter jedynie uzupełniający, podkreślający znaczenie jawności procedury zgłoszeń kandydatów do KRS, a nie wyłączający przepisy u.d.i.p.”; „Dokonana na tle powyższych ustaleń analiza treści art. 11c ustawy o KRS wykazuje, 
— po trzecie, potwierdzono, że dane w postaci imienia i nazwiska sędziego w żadnym razie nie mogą być chronione na podstawie przesłanki określonej w art. 5 ust. 2 udip;

— po czwarte - co było chyba najbardziej irracjonalne w kontekście uzasadnienia działań podejmowanych przez zobowiązanego - potwierdzono, że udzielenie poparcia przez sędziego musi mieć związek z pełnieniem przez niego funkcji publicznej. Abstrahując od szczegółowego uzasadnienia wyroków ${ }^{33}$, wystarczy stwierdzić, że gdyby konkretna osoba nie była sędzią, nie mogłaby takiego poparcia udzielić (oczywiście chodzi tu o poparcie co najmniej dwudziestu pięciu sędziów). Udzielenie takiego poparcia musi też wiązać się z użytym w art. 5 ust. 2 udip pojęciem „wykonywania funkcji” przez sędziego. Osoba niebędąca sędzią poparcia takiego (w liczbie dwudziestu pięciu popierających) nie mogłaby legalnie, a co za tym idzie skutecznie, udzielićs ${ }^{34}$;

— po piąte, wyraźnie sprecyzowano, że udostępnienie musi nastąpić po anonimizacji części danych — w tym wypadku numeru ewidencyjnego PESEL każdego sędziego popierającego konkretną kandydaturę ${ }^{35}$;

- po szóste wreszcie, wyraźnie podkreślono, że brak nośnika w postaci dokumentu nie uniemożliwia wywiązania się z obowiązku udostępnienia takiej informacji ${ }^{36}$.

że przepis ten nie odnosi się do zasad dostępu do informacji, lecz do trybu udostępniania informacji, o jakich w nim mowa, $\mathrm{i}$ to jedynie w ograniczonym podmiotowo i przedmiotowo zakresie, $\mathrm{tj}$. dotyczy Marszałka Sejmu, czyli podmiotu, który nie ma kompetencji do podejmowania działań w zakresie spraw zainicjowanych wnioskami o udostępnienie informacji publicznej oraz jedynie etapu postępowania prowadzonego przez Marszałka Sejmu" — wyrok NSA z dnia 28 czerwca 2019 roku, sygn. I OSK 4282/18.

33 „Informacja o aktywności konkretnych sędziów jako funkcjonariuszy publicznych, ukierunkowana na wyłonienie w ramach ustawowo przewidzianej procedury konkretnego składu konstytucyjnego organu, jakim jest Krajowa Rada Sądownictwa, i determinująca w znacznym stopniu skład tego organu, jest informacją o szczególnie istotnej sprawie wspólnoty publicznoprawnej” — wyrok NSA z dnia 28 czerwca 2019 roku.

${ }^{34}$ Przy tej okazji warto odnieść się do irracjonalnej tezy przekazywanej w środkach masowego przekazu, że w sytuacji podjęcia przez prezydenta RP (działającego w ramach swoich prerogatyw) aktu kreacyjnego dochodzi do legalizacji całego procesu nawet wtedy, gdy na wcześniejszych jego etapach pojawiły się naruszenia wymogów formalnych. Oznaczałoby to, że nie tylko legalizujemy naruszenia procedury, ale też że spełnienie wymogów formalnych przez kandydatów nie ma żadnego znaczenia.

35 „Udostępnienie wykazu sędziów popierających zgłoszenia kandydatów do KRS powinno nastąpić po uprzedniej anonimizacji numeru ewidencyjnego PESEL sędziego, który nie jest związany z pełnioną funkcją publiczną, a zatem nie powinien podlegać udostępnieniu” — wyrok NSA $\mathrm{z}$ dnia 28 czerwca 2019 roku.

36 ,[W]niosek z dnia 25 stycznia 2018 r., który zainicjował postępowanie zakończone decyzją zaskarżoną do Sądu I instancji, dotyczył załączników, jak i wglądu do nich, a zatem dotyczył zarówno dokumentu stanowiącego nośnik zawartej w nim informacji publicznej, jak i treści tego dokumentu, tj. właśnie zawartej w nim informacji publicznej. Podkreślić w związku z tym trzeba, że brak podstaw do utożsamiania informacji publicznej, jaką może stanowić sam dokument będący 
Mając to na względzie, należy się zastanowić, czy w następstwie wydanych rozstrzygnięć realne było zagrożenie naruszenia wolności i praw osób (sędziów), którzy udzielili poparcia, a o których informacja zostałaby udostępniona w wyniku upublicznienia wykazów poparcia.

Wątpliwości takie (tak przynajmniej należy sadzić) skutkowały wydaniem przez PUODO wskazanych wcześniej postanowień. Na pewno taką przeszkodą nie było bezpośrednie stosowanie — od 25 maja 2018 roku — postanowień RODO $^{37}$. W treści motywu 154 preambuły tego aktu podkreśla się bowiem znaczenie zasady publicznego dostępu do dokumentów urzędowych, której respektowanie musi mieć wpływ na stosowanie postanowień tego aktu. RODO nie stoi na przeszkodzie ani też nie wyłącza konieczności zagwarantowania uprawnionym publicznego dostępu do dokumentów urzędowych. Prawo dostępu do tego rodzaju dokumentów uznaje się jednocześnie za uzasadnione interesem publicznym. Natomiast $\mathrm{w}$ art. 86 RODO wskazuje się wprost na relację między przetwarzaniem danych osobowych a publicznym dostępem do dokumentów urzędowych. Stwierdza się w nim, że

Dane osobowe zawarte w dokumentach urzędowych, które posiada organ lub podmiot publiczny lub podmiot prywatny w celu wykonania zadania realizowanego $\mathrm{w}$ interesie publicznym, mogą zostać przez ten organ lub podmiot ujawnione zgodnie z prawem Unii lub prawem państwa członkowskiego, któremu podlegają ten organ lub podmiot, dla pogodzenia publicznego dostępu do dokumentów urzędowych z prawem do ochrony danych osobowych na mocy niniejszego rozporządzenia.

Mając to na uwadze, można stwierdzić, że z postanowień RODO wynika pewien model, opierający się na założeniach, zgodnie z którymi:

— przedmiotem udostępnienia mogą być dane osobowe zawarte w dokumentach urzędowych (zasada oficjalności, zgodnie z którą chodzi o dane zawarte nie w każdym dokumencie, ale w dokumencie urzędowym);

nośnikiem określonej treści, z informacją publiczną określoną właśnie treścią tego dokumentu jako jej nośnika. Oznacza to, że fizyczny brak dokumentu, którego treść musiała być organowi znana dla przeprowadzenia ustawowo określonej procedury i której ustawodawca nadał istotne znaczenie dla rozstrzygnięcia sprawy publicznej, nie wyklucza automatycznie możliwości udostępnienia informacji publicznej stanowiącej treść tego dokumentu" - wyrok NSA z dnia 28 czerwca 2019 roku, I OSK 4282/18.

37 Rozporządzenie Parlamentu Europejskiego i Rady (UE) 2016/679 w sprawie ochrony osób fizycznych w związku z przetwarzaniem danych osobowych i w sprawie swobodnego przepływu takich danych oraz uchylenia dyrektywy 95/46/WE. RODO uchyla i zastępuje dyrektywę 95/46/WE w obszarze sektorów prywatnego i publicznego w państwach członkowskich. Konieczne staje się jednocześnie podkreślenie, że oprócz RODO przyjęta została Dyrektywa Parlamentu Europejskiego i Rady (UE) 2016/680 z dnia 27 kwietnia 2016 roku w sprawie ochrony osób fizycznych w związku z przetwarzaniem danych osobowych przez właściwe organy do celów zapobiegania przestępczości, prowadzenia postępowań przygotowawczych, wykrywania i ścigania czynów zabronionych i wykonywania kar, w sprawie swobodnego przepływu takich danych oraz uchylająca decyzję ramową Rady 2008/977/WSiSW — tak zwana dyrektywa policyjna (Dz.U. UE z 4 maja 2016, L119). 
— dokumenty te muszą znajdować się w posiadaniu organu będącego adresatem wniosku, a takie dane są przetwarzane w celu wykonania zadania realizowanego w interesie publicznym ${ }^{38}$;

— ujawnienie takie następuje w ramach ważenia (pogodzenia, testu szkody) publicznego dostępu do dokumentów urzędowych z prawem do ochrony danych osobowych (zasada ważenia interesów) ${ }^{39}$.

Dotychczasowa praktyka udostępniania informacji publicznych dotyczących osób pełniących funkcje publiczne (w tym sędziów) doprowadziła już wcześniej — również pod rządami poprzednio obowiązującej ustawy o ochronie danych osobowych $^{40}$ — do wypracowania modelu, w którym przekazanie informacji wiąże się z anonimizacją części danych osobowych (identyfikatorów) w zakresie, w którym nie stanowią one informacji publicznej (na przykład numer PESEL), $\mathrm{z}$ jednoczesnym zastrzeżeniem, że prywatność takich osób jest $\mathrm{w}$ odniesieniu do osób takich funkcji niesprawujących w stopniu zdecydowanie węższym chroniona. Ochronie takiej nie może podlegać jednak imię i nazwisko osoby pełniącej funkcję publiczną czy miejsce (stanowisko) zatrudnienia. Irracjonalne byłoby przy tym założenie, że ochronie podlega fakt udzielenia poparcia kandydaturze innego sędziego (i to czynnego w związku z ustawowym wyłączeniem możliwości udzielenia poparcia przez sędziego w stanie spoczynku) w zakresie ubiegania się o uzyskanie statusu członka KRS.

Na koniec tej części istotne jest jeszcze odniesienie się do postanowienia WSA z 24 stycznia 2020 roku, które dotyczyło legalności postanowień PUODO. Sąd

38 Jak zauważył GIODO w odniesieniu do stanu prawnego obowiązującego przed 25 maja 2018 roku, należy „wyraźnie podkreślić, że aby kryterium »niezbędności dla realizacji zadań« mogło zostać uznane za wystarczające określenie zakresu tego udostępniania na rzecz ww. podmiotów, to w pierwszej kolejności - z przepisów prawa - wynikać powinno, że podmioty te mają obowiązek wykonywania określonych zadań i w związku z tym muszą one mieć dostęp do określonych informacji. Innymi słowy, to z regulacji ustawowej winno wynikać, że w celu skutecznego wykonywania obowiązków wskazanej grupie podmiotów przysługuje prawo dostępu do informacji związanych z prywatnością osób fizycznych" - pismo GIODO z dnia 27 września 2013 roku, DOLiS-033-70/13/MK/63214. Na temat pojęcia „zadanie publiczne” w rozumieniu przepisów prawa krajowego zob. G. Sibiga, Kryterium ,zadania publicznego” w ustawie z 10.5.2018 r. o ochronie danych osobowych oraz jego konsekwencje dla wykonywania obowiązów administratora oraz realizacji praw osoby, której dane dotycza, „Monitor Prawniczy” 2018, dodatek nr 22. Przepisy prawa uzupetniajace RODO. Aktualne problemy prawnej ochrony danych osobowych 2018, red. G. Sibiga, s. 8-14.

39 Już dawno temu sądy podkreślały, że „Z zestawienia dwóch wartości, tj. zasady jawności informacji publicznych oraz obowiązku ochrony prywatności, tajemnic przedsiębiorcy i danych osobowych osób fizycznych, można wyprowadzić wniosek, że dopuszczalne jest udostępnianie informacji publicznej, ale w sposób nienaruszający wskazanych dóbr chronionych. Służy temu m.in., zastosowana przez organ w rozpatrywanej sprawie, tzw. anonimizacja danych wrażliwych" - wyrok NSA z dnia 9 sierpnia 2011 roku, sygn. I OSK 976/11; por. wyrok NSA z dnia 11 stycznia 2013 roku, sygn. I OSK 2267/12.

40 Ustawa z dnia 29 sierpnia 1997 roku o ochronie danych osobowych (Dz.U. Nr 133, poz. 883 ze zm.). 
jednoznacznie podniósł bowiem bezzasadność powoływania się przez PUODO na postanowienia ustawy o ochronie danych osobowych z 10 maja $2018 \mathrm{roku}^{41}$. Działania PUODO nie mogą wstrzymywać wykonania prawomocnych orzeczeń sądu. Taka postać ingerencji w sprawowanie wymiaru sprawiedliwości jest po prostu niedopuszczalna na tym etapie sprawy. Zastanawiający przy tym jest właśnie moment zainicjowania działań przez PUODO, to znaczy wydanie postanowień kilkadziesiąt dni po wydaniu prawomocnego orzeczenia NSA, który jednoznacznie określił zakres udostępnienia, obejmujący dane identyfikujące osobę pełniącą funkcję publiczną z jednoczesnym wskazaniem, jakie identyfikatory takiemu udostępnieniu nie podlegają.

\section{KONKLUZJE}

Na koniec warto zauważyć, że cała sytuacja związana z ostatecznym upublicznieniem przez kancelarię Sejmu list poparcia kandydatów na członków KRS doprowadziła nie tylko do deprecjacji powagi sądu czy znaczenia prawomocnie wydanego przez ten sąd wyroku. Przede wszystkim doszło do osłabienia kreowanych z dużym wysiłkiem przez ostatnich dwadzieścia lat standardów jawności i przejrzystości funkcjonowania organów władzy publicznej i reprezentujących je osób pełniących funkcje publiczne. Okazało się bowiem, że ujawnienie konkretnej informacji następuje dopiero wtedy, gdy sam zobowiązany uzna, że w określonej sytuacji polityczno-prawnej ${ }^{42}$ opłaca mu się to zrobić. Nie miało przy tym znaczenia, że jednocześnie działanie takie prowadzi do zaprzeczenia niezależności, a nawet szerzej - sensowności, funkcjonowania w polskim porządku prawnym krajowego organu ochrony danych osobowych. Okazało się bowiem, że dla zobowiązanego postanowienia PUODO - choć akurat w tym wypadku od razu było wiadome, czemu one służą — nie mają większego prawnego znaczenia i mogą być skutecznie ignorowane, oczywiście po osiągnięciu swojego celu, jakim stało się przeciąganie momentu ujawnienia tej informacji publicznej.

W następstwie tej sprawy doszło więc nie tylko do umniejszenia roli i znaczenia sądów jako organów wymiaru sprawiedliwości, lecz także do wykazania iluzoryczności charakteru i sposobu działania krajowego organu ochrony danych osobowych. Co więcej, sposób postępowania zobowiązanego, jak też charakter zainicjowania postępowania przez PUODO stworzyły niebezpieczny precedens na przyszłość, którego kontunuowanie przez kolejne osoby pełniące funkcje publiczne jest tylko kwestią czasu.

\footnotetext{
${ }^{41}$ Tekst jedn. Dz.U. z 2019 r. poz. 1781.

${ }^{42}$ Chodzi tu o wejście w życie z dniem 14 lutego 2020 roku tak zwanej ustawy kagańcowej.
} 


\title{
DATA OF JUDGES SUPPORTING CANDIDATES' SUBMISSIONS AS PUBLIC INFORMATION FROM THE NATIONAL COUNCIL FOR THE JUDICIARY
}

\author{
Summary
}

The fundamental issue raised in this elaboration comes down to a trial of relating to the recognition of the content of the annexes to the submissions of candidates for members of the National Council for the Judiciary for public information.

Keywords: public information, transparency, restriction of access to public information, National Council for the Judiciary, annexes to applications of candidates for members of the National Council for the Judiciary, privacy

\section{BIBLIOGRAFIA}

Boć J., Komentarz do art. 60 Konstytucji RP, akapit II, [w:] Konstytucje Rzeczypospolitej oraz komentarz do Konstytucji RP z 1997 roku, red. J. Boć, Wrocław 1998.

Dostęp do informacji publicznej, red. P. Szustakiewicz, Warszawa 2019.

Dostep do informacji publicznej na wniosek w praktyce jednostek samorzadu terytorialnego, red. J. Wyporska-Frankiewicz, Warszawa 2019.

Jabłoński M., Udostępnienie informacji publicznej w formie wgladu do dokumentu, Wrocław 2013.

Piskorz-Ryń A., Obowiazki informacyjne sadu w świetle ustawy o dostępie do informacji publicznej, „Orzecznictwo Sądu Apelacyjnego w Łodzi” 2015, nr 2. Sędzia — osoba publiczna czy prywatna? Granice dostępu do informacji publicznej i ochrona danych osobowych.

Sakowska-Baryła M., Wspótstosowanie ustaw o dostepie do informacji publicznej i ochronie danych osobowych przy udostepnianiu informacji o osobie petniacej funkcję publiczna, „Orzecznictwo Sądu Apelacyjnego w Łodzi” 2015, nr 2. Sędzia - osoba publiczna czy prywatna? Granice dostępu do informacji publicznej i ochrona danych osobowych.

Sibiga G., Kryterium ,zadania publicznego ” w ustawie z 10.5.2018 r. o ochronie danych osobowych oraz jego konsekwencje dla wykonywania obowiąków administratora oraz realizacji praw osoby, której dane dotycza, „Monitor Prawniczy” 2018, dodatek nr 22. Przepisy prawa uzupetniajace RODO. Aktualne problemy prawnej ochrony danych osobowych 2018, red. G. Sibiga.

Tomaszewska K., Dostęp do informacji publicznej w świetle obowiązujacych i przyszlych regulacji, Warszawa 2019.

Wilbrandt-Gotowicz M., Prywatność osoby fizycznej jako ograniczenie jawności informacji publicznych (w świetle orzecznictwa sadów administracyjnych), [w:] Jawność i jej ograniczenia, t. 4. Znaczenie orzecznictwa, red. M. Jaśkowska, Warszawa 2014. 